\title{
MPRA
}

Munich Personal RePEc Archive

\section{Interruptions and failure in higher education: evidence from ISEG-UTL}

\author{
CHAGAS LOPES, MARGARIDA and LEAO \\ FERNANDES, GRAÇA
}

SOCIUS - RESEARCH CENTRE IN ECONOMIC AND ORGANIZATIONAL SOCIOLOGY, CEMAPRE - CENTRE FOR APPLIED MATHEMATICS AND ECONOMICS

17 October 2011

Online at https://mpra.ub.uni-muenchen.de/34227/ MPRA Paper No. 34227, posted 20 Oct 2011 16:39 UTC 


\title{
"Interruptions and Failure in Higher Education: evidence from ISEG-UTL"
}

\section{Margarida Chagas Lopes ${ }^{1,2}$ (mchagaslopes@gmail.com) and Graça Leão}

Fernandes ${ }^{1,3}$ (gleao@iseg.utl.pt)

1. ISEG (School of Economics and Management, Technical University of Lisbon, Portugal); 2. SOCIUS (Research Centre in Economic and Organizational Sociology);

3.CEMAPRE (Centre for Applied Mathematics and Economics)

\begin{abstract}
Failure in Higher Education (HE) is the outcome of multiple time-dependent determinants. Interruptions in student's individual school trajectories are one of them and that's why research on this topic has been attracting much attention these days.
\end{abstract}

From an individual point of view, it is expected that interruptions in school trajectory, whatever the reason, influence success in undergraduate programs either this success is measured by time required to obtain a degree, the scores obtained in some more "critical" subjects in these programs or the number of enrolment registrations. Nevertheless, performing a paid job during interruption may in given circumstances positively affect academic success on account of the combination between learning and occupational experience

The study of interruptions' impact on failure in HE is also important to help Education institutions at all grades to think about changes in organisational procedures, class timetables, syllabuses contents or teachers recruitment and training in order to fight this problem.

From a social and political point of view, interruptions are also a matter of concern since failure in HE affects individual's lifelong learning opportunities, distort public funding allocation efficiency to HE institutions and create lag effects in the desired/planned outcomes of HE production functions. So, research on the impact of interruptions on failure in HE is important to support policy measures definition related to the articulation between Upper Secondary and HE programs. 
In previous research we have shed some light into the determinants of failure in 1st year of HE studies using longitudinal data on ISEG's undergraduate students. A further insight into this database revealed the existence of a meaningful number of students with interruptions in their school trajectories either in the transition from Upper Secondary to HE or within HE programs.

In this paper our major concern is to find some evidence on interruptions effects on HE failure among ISEG students using a life cycle approach with control group. We are interested in knowing whether the above mentioned effects are gender and/or specific graduation program neutral. We also want to search if work experience may counter balance the effect of interruption on academic success. We hope to be able to derive some useful recommendations to address policy making in the fields of pedagogic methodologies in HE, articulation between academic and occupational learning in the framework of Bologna Chart and public funding/fellowship policies in HE.

Key words: Portuguese Higher Education; Interruption; Failure; Adult Students; Bologna Chart; Policy Implications 


\section{Introduction:}

It is more and more consensual that Higher Education (HE) plays a dominant role in fostering overall labor productivity and non-price competitiveness, besides the multiplier effects spread all over the society in terms of quality of life, democratic participation and social inclusion and (re)equilibrium.

In most countries, as Portugal, HE has to play an increased role on the up skilling of the present occupational structure in which even knowledge intensive services (KIS) - where larger gains in productivity have been obtained in today's economies - seem unable to absorb high skilled employment: only 23,1\%, in 2006, the third worst result after Bulgaria and Romania, against 32,8\% in EU-27 (Parvan 2007).

Graduation rates have been steadily increasing since the late eighties, when the income conditions provided by democracy led to a generalized access to $\mathrm{HE}$ and private universities spread taking advantage of the government's failure to satisfactorily correspond to the increased demand. Between 1991 and 2008, graduation rates increased for about 4,5 times (PORDATA, http://www.pordata.pt/azap runtime/?n=4) and almost tripled in the Engineering related areas.

Despite that overall positive trend roughly $60 \%$ of the enrolled successfully complete graduation. Unfortunately there is not a systematic official procedure for computing quitting in the Portuguese HE. The studies which approach the main determinants of those processes generally conclude on the importance of the role played by having to reconcile $\mathrm{HE}$ attendance with the performance of a paid job, the impact exerted by individual's age, gender and family's social-economic status.

We aim to find some evidence on interruptions effects on HE failure among ISEG students using a life cycle approach with control group. We are interested in knowing whether the above mentioned effects are gender and/or specific graduation program neutral and if work experience may counter balance the effect of interruption on academic success. 
We use the database of the Pedagogic Observatory of ISEG which provides us semi-longitudinal data on students' academic trajectories, students' situation towards employment, characterization of students' fathers' and mothers' education levels, among other.

A specific survey on interruption and quitting addressed by the Pedagogic Observatory gives us information on the main causes indicated by students/former students who had suffered interruption and/or quitting processes. It also has information on students' opinions on some important characteristics of ISEG's organization model, namely administrative facilities to reconcile study and work (class shifts...), evaluation regimen, perceived quality of teaching, among other, in line with other studies as for instance Yorke \& Londen (2008) .

We hope to be able to derive some useful recommendations to address policy making in the fields of pedagogic methodologies in HE, articulation between academic and occupational learning in the framework of Bologna Chart and public funding/fellowship policies in HE.

\section{Portugal in the context of EU: survey of literature and evidence}

A full range of studies on interruptions in HE is now available, but not in Portugal to our knowledge. The studies differ mainly in terms of the analytical methodology some of them analyse just a given cohort, others try to develop comparative statistics and compare several cohorts inside the same institution. These analyses also differ on the set of explanatory variables they associate with interruptions. With regard to this last criterion we can distinguish three kinds of approaches:

- One which sets as leading factors both individual difficulties (e.g. being displaced) and families' social and economic status, generally associated with income restrictions; 
- One which integrates mainly adult economically autonomous students who have to combine work and study and whose main reasons for interruption derive from the difficulties in reconciling these two activities.

- One which is mainly concerned with the HE institution's organisation procedures, syllabus contents, evaluation and pedagogical models, among others.

Let us briefly consider some research which illustrates each of the above approaches.

Self-orientation, commitment and work-life conciliation are the leading factors stressed by Makinen et al (2004) in their analysis of interruptions by $1^{\text {st }}$ year students from a Finnish university. They subdivide students into three categories: the study oriented, the work-life oriented and the non-committed. They show that while the noncommitted are the most prone to abandoning studies, the work-life oriented obtain higher study credits and display a higher probability of graduating. Therefore, reconciling studying and a professional occupation could be advantageous in certain situations.

Parri \& Aas (2006) analysed a cohort of students in Estonia, to ascertain the influence of the national examination score obtained by students at the end of Secondary Education on both the length of studies and the probability of interruption in HE. They found that students with lower scores faced higher probabilities of interruption. But when controlling for the kind of funding and the public/private nature of the HE institution the former effect vanished and only the latter remained meaningful. Having observed that completion rates were higher and probabilities of interruption lower among Estonian larger public institutions they looked at organisational and pedagogical features and concluded that quality of teaching and resources offered for teaching and learning, regulation of studies (e.g. the nuclear structure) and evaluation policy are the main determinants of interruption.

Jacob and Weiss (2008) focus on the main reasons behind returning to school after having interrupted HE studies in a comparison of Germany and the USA. Besides individual characteristics such as age when entering $\mathrm{HE}$, a set of quite pertinent factors 
appeared as the outcome of the analysis, namely: the public/private nature of the educational institution, the degree of programme standardization, the degree of flexibility within the labour market, the tenure associated with professional experience and the parallel/sequential nature of the study and working trajectories.

Yorke \& Longden (2008) compare two identical surveys addressed to $1^{\text {st }}$. year students with some years of interval to study "stop out" and interruption in UK universities. As leading determinants for quitting and interruption, the authors find evidence of a set of factors common to the two surveys. Quitting and/or interruption are mainly due to a poor scholar orientation towards the course, a lack of self-commitment, dissatisfaction with teaching quality and professors' support as well as with university's physical resources, financial constraints and family's responsibilities. Among the later Yorke \& Longden point to a greater pressure from financial constraints suffered by older students who have to reconcile family chores with work and study. Also students' social and economic background seem to display a meaningful influence, with students coming from families where there was already a graduation degree risking less to face interruption or stopping out.

Beyond these studies in the EU context which will serve for the purpose of comparison of the results in our study, there are two more interesting studies.

The research group at Moscow Lomonosov University coordinated by I.G. Teleshova (no date) stresses the importance of taking the probability of interruption in the evaluation of the effective equality of opportunities not only to access HE but especially to graduate successfully. The social and economic origin of the students' family, the place of residence and the eventual need to be displaced for studying, education costs and programme length are presented as the leading factors behind interruption. Gender too is discussed as an important factor as well as administrative and pedagogic variables. However, the research only focuses on one cohort allegedly because the variables would not change meaningfully over time.

Relying upon data from the American National Longitudinal Survey the study by Scott and Bernhardt (2000) stresses the fact that for most students with few economic resources interruption to perform a paid occupation and returning later to school is the 
only way to continue studying. Advice on financial help, flexible attendance procedures and innovation in administration's programme are the key stones for these authors.

From this brief review we retain the following as main variables:

- Students' gender and age;

- SES (social and economic status) of the family of origin;

- Score obtained in the university entry examination;

- The need to perform paid work, prior to and during the interruption;

- Objective and subjective opportunities and administrative facilities to reconcile study and work (class shifts...), evaluation regimen, perceived quality of teaching...;

- Time interdependence between insertion and performance within the labour market and HE application and attendance trajectories.

The need to perform a paid job due to heavy budget constrains to finance HE is a transversal feature to the factors we mentioned above. To place our study in the EU context which we take as a reference, we present some main indicators of the weight of HE costs in individual andlor family budget as well as in public financing in our country and some EU members.

In Portugal HE students have to pay tuition as well as registration fees (the yearly tuition fees being heavier than the registration fees). Tuition fees for full time students enrolled for 1st qualification in 2005/2006 range from 583 to 1082 EUR while the values for other EU countries, with similar tuition schemes, for the same year are displayed in Table 1:

Table 1: GDP p.c. and Tuition fees in some EU countries

\begin{tabular}{|l|l|l|l|l|}
\hline & $\begin{array}{l}\text { GDP per capita } \\
\text { in PPS } \\
\text { (EU-27 2005 }= \\
100) \\
(1)\end{array}$ & Rank Order & $\begin{array}{l}\text { Tuition Fees } \\
\text { 2005 (PPS €) } \\
\text { Minim. - Maxim. } \\
(2)\end{array}$ & \\
\hline EU-27 & 100 & & $\begin{array}{l}\text { Rank } \\
\text { Order }\end{array}$ \\
\hline $\begin{array}{l}\text { Czech } \\
\text { Republic }\end{array}$ & 75,9 & $(7)$ & $149-298$ & $(7)$ \\
\hline
\end{tabular}




\begin{tabular}{|l|l|l|l|l|}
\hline Portugal & 77 & $(6)$ & $583-1082$ & $(3)$ \\
\hline Spain & 102 & $(5)$ & $516-1109$ & $(4)$ \\
\hline Belgium (fr.) & 119,8 & $(4)$ & $153-705$ & $(6)$ \\
\hline UK & 121,9 & $(3)$ & 1579 & $(1)$ \\
\hline Austria & 124,5 & $(2)$ & 701 & $(5)$ \\
\hline Netherland & 130,8 & $(1)$ & 1406 & $(2)$ \\
\hline
\end{tabular}

Source: EUROSTAT Database

(Acc:http://epp.eurostat.ec.europa.eu/portal/page/portal/statistics/search_database, 23rd February 2010).

Relying on this data we can argue that HE access in Portugal is heavily conditioned by the budget constraints of the student andlor their families. Actually, budget constraints are one of the main reasons for interruption and drop-out.

Besides, the Portuguese model of HE financing is comprehensive and relies almost exclusively on grants. 
Figure 1: Public Subsidies for Education in Tertiary Education (2006)

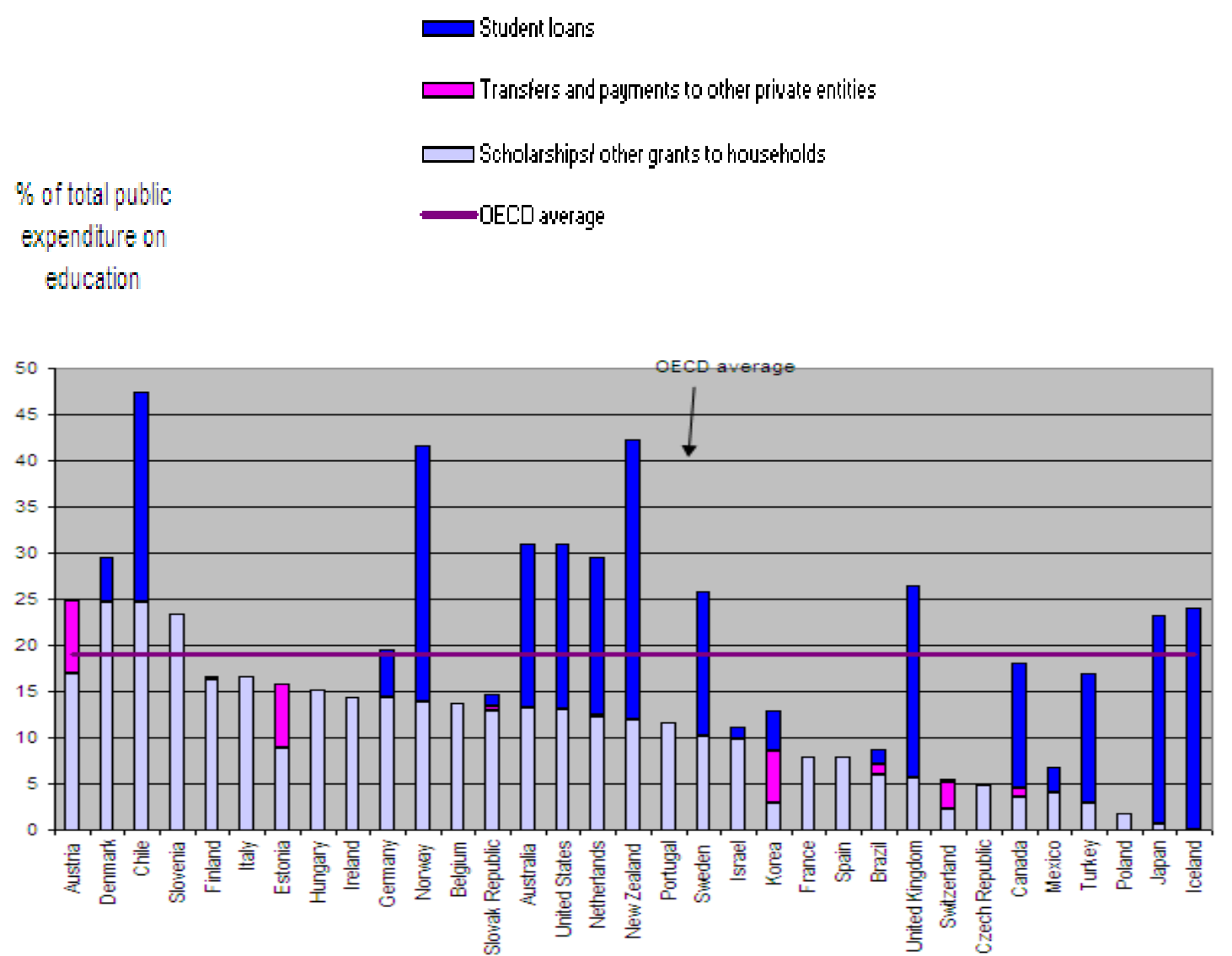

Source: Adapted from OECD (2009), Education at a Glance

Figure1 shows that, among the EU members which rely only on grants as public financial assistance to HE, exception made for Spain, Czech Republic and Poland ${ }^{1}$, Portugal is the country where the percentage of public subsidies to HE is the lowest. As the costs of tuition fees in Portugal are relatively higher and our GDP per capita relatively lower when compared to some of our EU partners (Table 1), the lower public support through grants can only become more severe as the budget constraints faced by the students or their families are growing due to the present crisis

Lower public support lie probably among the main determinants for the very modest figures relative to successful completing HE in Portugal, as shown in figure 2:

\footnotetext{
${ }^{1}$ We don't mention France because the French model of HE financing and tuitions is not comparable with the EU members we are comparing us with.
} 
Figure 2: "Survival rates" in the first cycle of tertiary education (ISCED 5B and 5A)(Base: number of graduates in 2004)

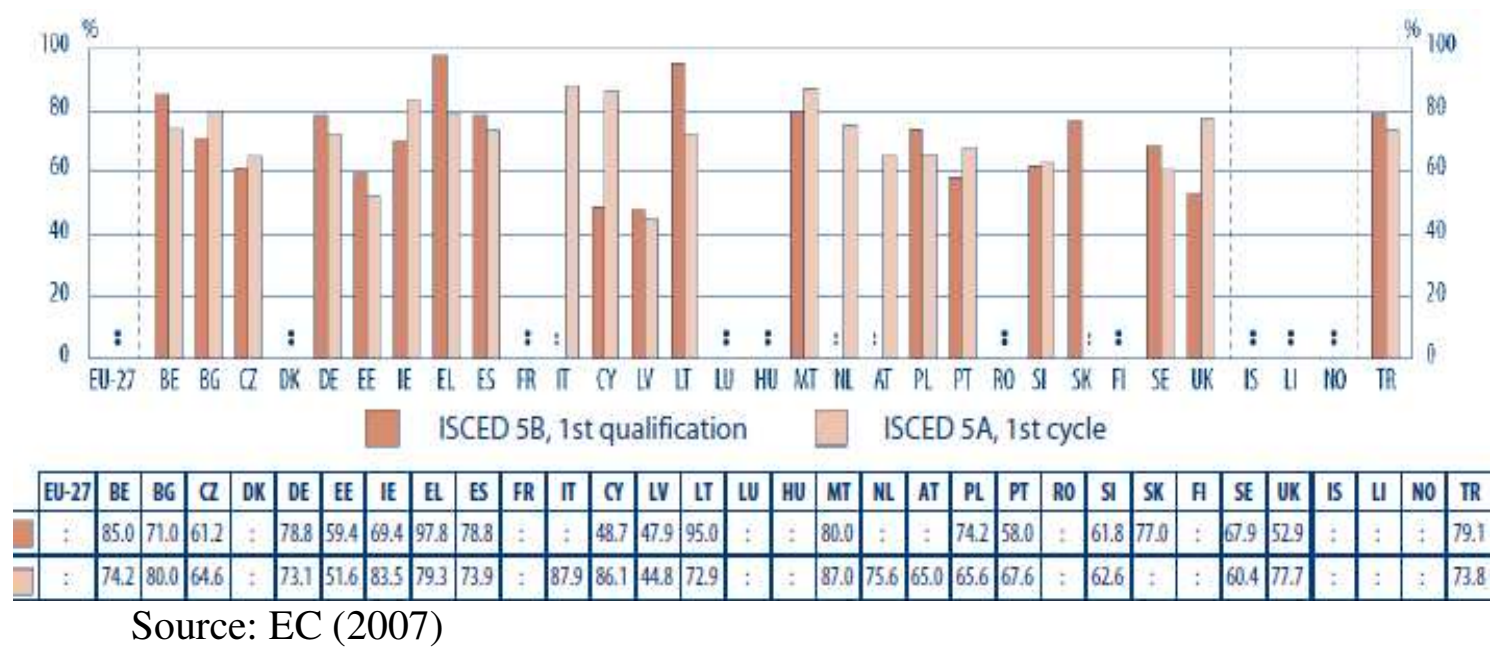

In the above Figure, tertiary education data has been reported following the International Standard Classification of Education (ISCED). Accordingly, ISCED 5A refers to HE theory-based programs leading to further advanced studies among other occupations, ISCED 5B to shorter and more technical/practical training mostly tailored for direct entry into the labor market (OECD 2002). As it can be seen, survival rates in Portuguese Higher Education (HE) remain lower than EU-27 average for ISCED 5A as well as for ISCED 5B $(67,6 \%, 58,0 \%$ for ISCED 5A \& 5B (EC 2007). This means that only about 6 among each 10 students previously enrolled successfully complete HE.

Figure 3: Breakdown of students in tertiary education according to level of programme (ISCED $5 \mathrm{~A}, 5 \mathrm{~B}$ and 6), 2003-2004

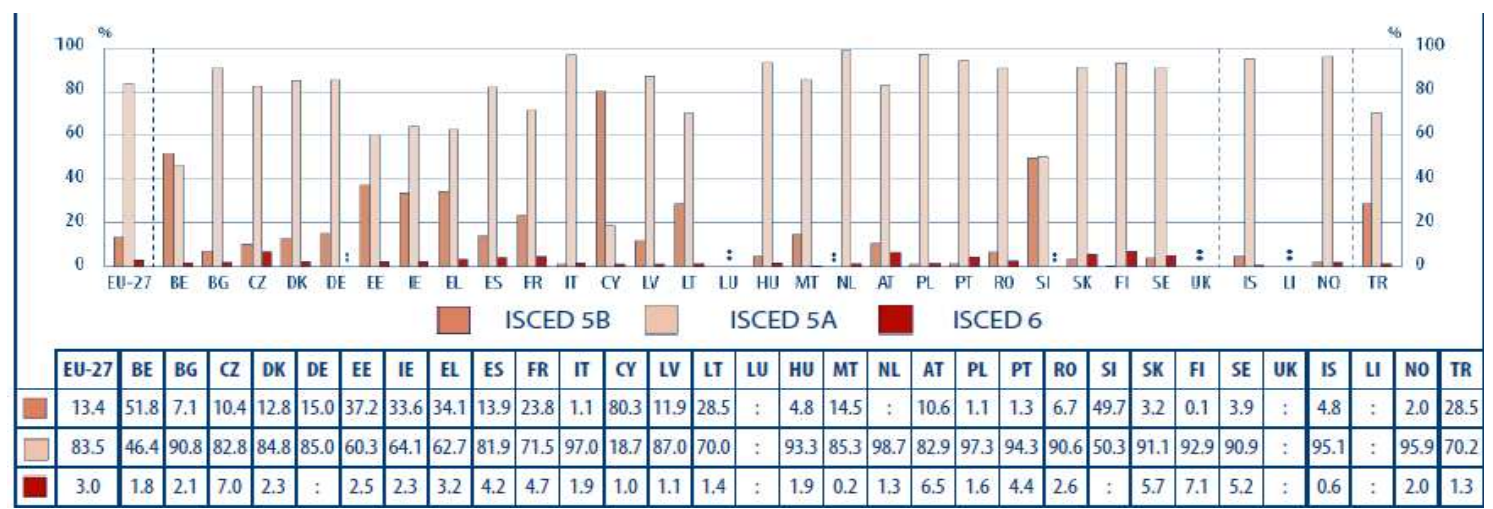

Source: EC (2007)

Figure 3 clearly reveals that breakdown affects 5A students much more than 5B students, in the Portuguese HE. It also shows that the Portuguese tertiary education 
suffers from important deadweight losses which we must analyse in order to identify the main obstacles to success.

Among the ISEG students who enrolled $1^{\text {st }}$. year $1^{\text {st }}$ time in 2005 the percentage who completed the graduation in due time is around $37 \%$ and interruption seem to severely affect HE trajectories. Besides retention rates, which has been the focus of previous studies, quitting ${ }^{2}$ and interruption ${ }^{3}$ seem to affect Portuguese HE trajectories severely.

To understand and explain the above figures becomes even more crucial now that the Bologna Process implementation has brought about huge changes in the degree programmes. These changes tend to adapt the previous HE curricula contents (first degree programmes that took 4 or 5 years) to a much shorter duration ( 3 for most of the HE programmes) with only minor syllabuses cuts and meaningful negative side effects in terms of scholar success (Lüede 2008; Musselin 2009). Those pedagogic and organizational changes are expected to have a significant impact in Portuguese HE too.

\section{Theoretical Approach}

These kinds of analyses pertain to the critical assessment of human capital theories $\left(\mathrm{HCT}^{4}\right)$ and the proposal of more realistic alternatives such as life cycle theories ${ }^{5}$.

Actually, neither education nor training trajectories necessarily follow a continuous and linear pattern. Nor do they finish just before the individual's insertion into the labour market. If we continued supporting this hypothesis there would not be room for the theoretical consideration of lifelong learning and what is commonly called new learning opportunities. Of course HCT don't reject learning opportunities once in the labour market; as a matter of fact, most reference authors have been quite concerned with the effect of occupational experience and vocational/professional training on workers' skills. But these approaches usually discard the role formal education can play

\footnotetext{
${ }^{2}$ By quitting we mean the students that quit HE studies and didn't come back in a five years period.

${ }^{3}$ By interruptions refer to students who quitted but came back in a length time less than five years.

${ }_{5}^{4}$ As developed by Gary Becker (1964) and Jacob Mincer (1958) in their seminal works.

${ }^{5}$ Bidart and Lavenu ( 2005).
} 
after insertion into the labour market, or during inactivity, unemployment or employment spells.

HCT generally neglect the diversity of roles that individuals actually play as an outcome of the multiple trajectories which encompass life cycles: education and training trajectories, vocational and occupational ones, transitions relative to a family's situation, and others. In fact there is indeed no reason for those trajectories not to be juxtaposed.

We are perfectly aware of the time dependency effects which characterize those trajectories' interaction: individual labour market outcomes are usually dependent on the previous school trajectory; further studying decisions and opportunities strongly depend upon previously made school track choices, scores obtained, field of studying. Education and training trajectories are also deeply intertwined with the family's social and economic status and family transitions; both of them are quite contingent upon and deeply condition "new" learning opportunities. In the next Figure we try to plot the interplay among some of the above trajectories during an individual life cycle: 
Figure 4: Interaction among life cycle trajectories

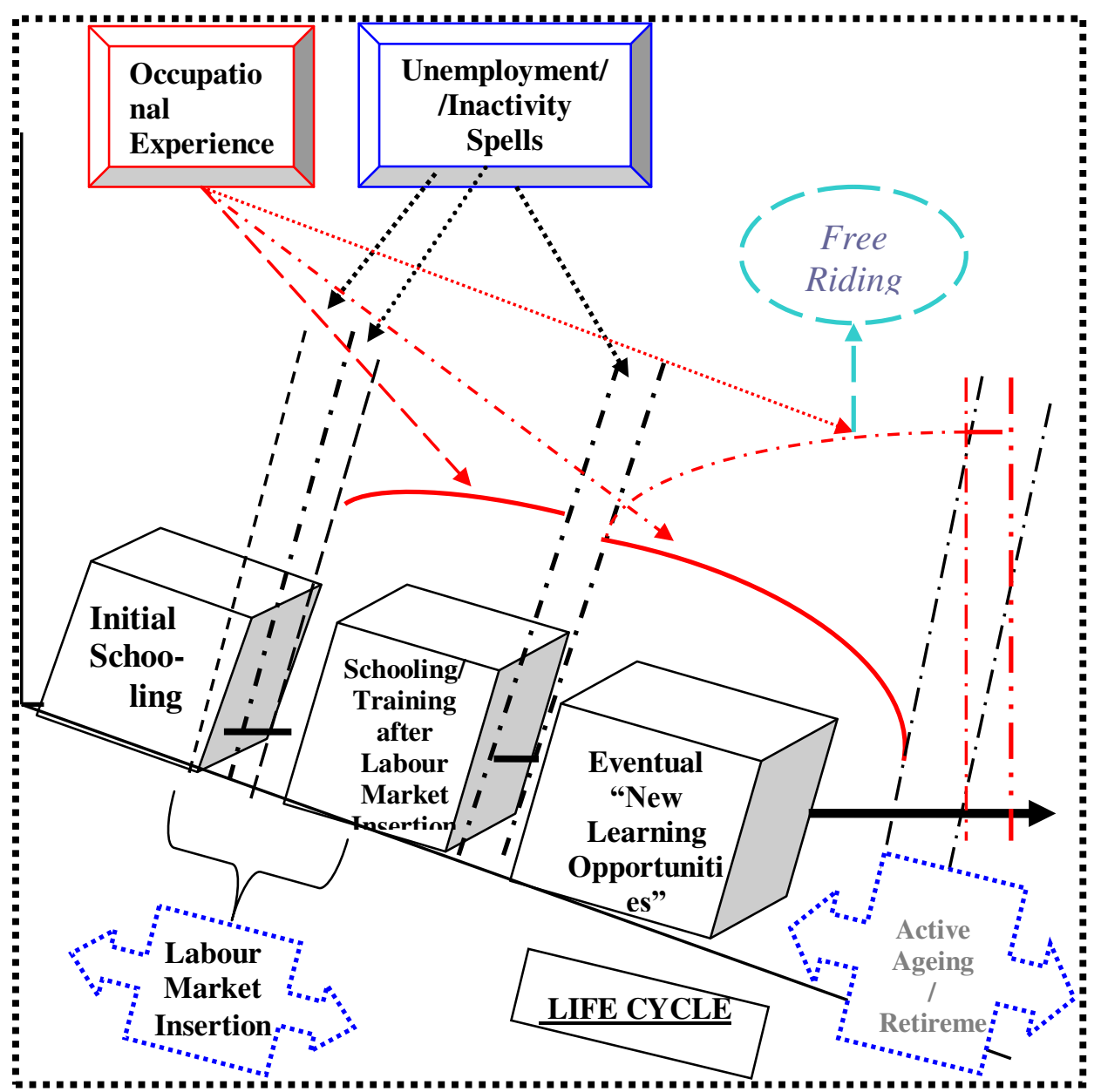

Source: Adapted from Chagas Lopes (2007)

The question which concerns us the most in this paper has to do with the education and training trajectories. As can be seen from the above representation, two interruption spells are represented in this example, one at the time of labour market insertion, the second in the middle of active life. We allow formal education/training after labour market entry and (eventually) "new learning opportunities" as depicted by the second and third education blocks, respectively.

In view of this paper's main purpose, and referring to Figure 4, we consider that HE can be represented by each of the three education blocks: it can take place at different moments in the individual life cycle (each one of the three education blocks). Of course, attending and trying to complete HE before entering the labour market (and possibly before any family transition as well), the first block, would ceteris paribus become easier for a given family's social and economic status and previous school 
performance. Nevertheless, occupational experience may in some situations contribute to improving academic performance as we have already referred ${ }^{6}$.

Variables like the above must therefore be taken into account when we study success and failure in HE. They are also important in the study of interruptions.

\section{Data and Methodology}

In this study we use data gathered by the ISEG Pedagogic Observatory. ISEG is the School of Economics and Business Management, the second largest School, of the Technical University of Lisbon.

Our data set merged data on all students (82) who experienced interruptions in their HE trajectory from the moment they entered HE until 2007 and a random sample of 106 students who entered HE at ISEG on the same period but graduated 4 years after entering HE. We took six cohorts with HE entrance from 1997 to 2002 in order to control for changing graduation programs and selectivity level at the HE entry exam.

The random sample was chosen so that the weight of year $t(t=1997, \ldots, 2002$.) students in the sample is approximately equal to the same weight in the data set on students who experienced interruptions, since we use successful students as a control group in the study of the performance of those whose HE trajectory is characterized by interruption

episodes.

We had information on individual characteristics (sex, age at the moment they entered HE, civil status, participation in labour market, HE entry-exam score), parents' socio-economic background (mother's and father's educational level, situation regarding occupation and employment), proxies of success/failure in HE (number of

\footnotetext{
${ }^{6}$ Willis (1987).
} 
failures before success in some core $1^{\text {st }}$ year subjects of HE [Maths I, Economics I and Introduction to Management].

Thus, our data set had 188 observations, and a variable IDENT which takes value 1 if the observation belongs to the graduate data set and 2 for students who experienced interruptions. We began by characterizing both groups with regard to individual characteristics, parents' socio-economic background and performance in HE.

Further, in a first step towards a deeper insight into the characterization of the students with interruptions in their HE trajectory, using graduate students as a control group, we performed Chi-Square tests to see if the distribution in the two groups of the discrete variables is dependent on the group to which the observations belong.

For the continuous numeric variables, age at HE entrance and average score, number of failures before success in Maths I, Economics I and Introduction to Management, we carried $t$-student Compare Means for Independent Samples Test.

\section{Some results}

The students whose HE trajectories are characterized by one or more interruptions are mostly males (58.5\%), aged between 19 and 20 years old at entry to HE (46.3\%), and unmarried (96.3\%). Most of them participated in the labour market $(62.9 \%)$ either with a full time job $(46.3 \%)$ or a part time job (19.5\%). They arelwere mainly in the Management Degree Program (57.7\%). Most of them experienced interruptions in the HE trajectory in their third curricular year although some did it in their first one [Figure 5]. 
Figure 5

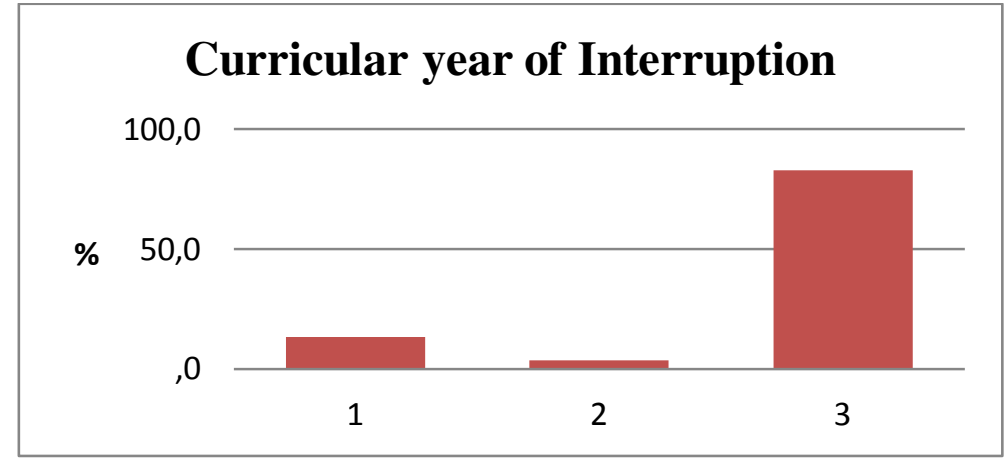

From those who interrupted their studies in their first year, $63.6 \%$ successfully passed at most 3 subjects out of the 12 programmed for the first year. Among those who interrupted in the third year, $42.6 \%$ had been successful in fewer than 24 subjects. Their passing grades are low, an average close to 11 (out of 20) at the moment they broke off and display a high number of failures in the core subjects of $1^{\text {st }}$ year $\mathrm{HE}$ as shown by Figures 6, 7, 8:

Figure 6

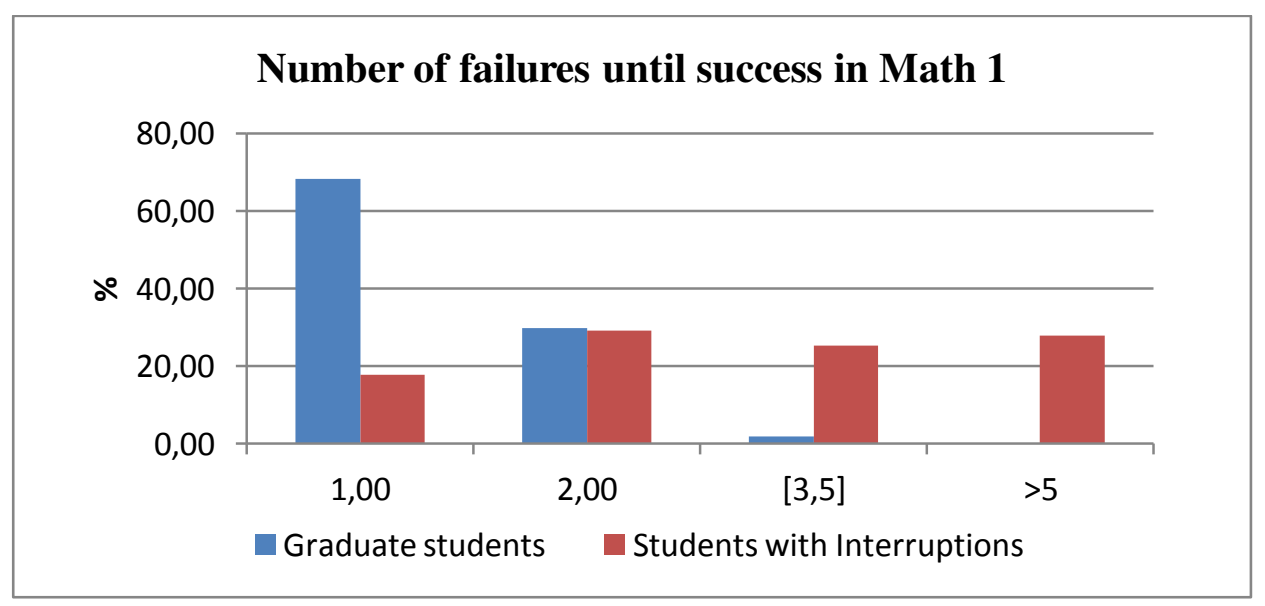


Figure 7

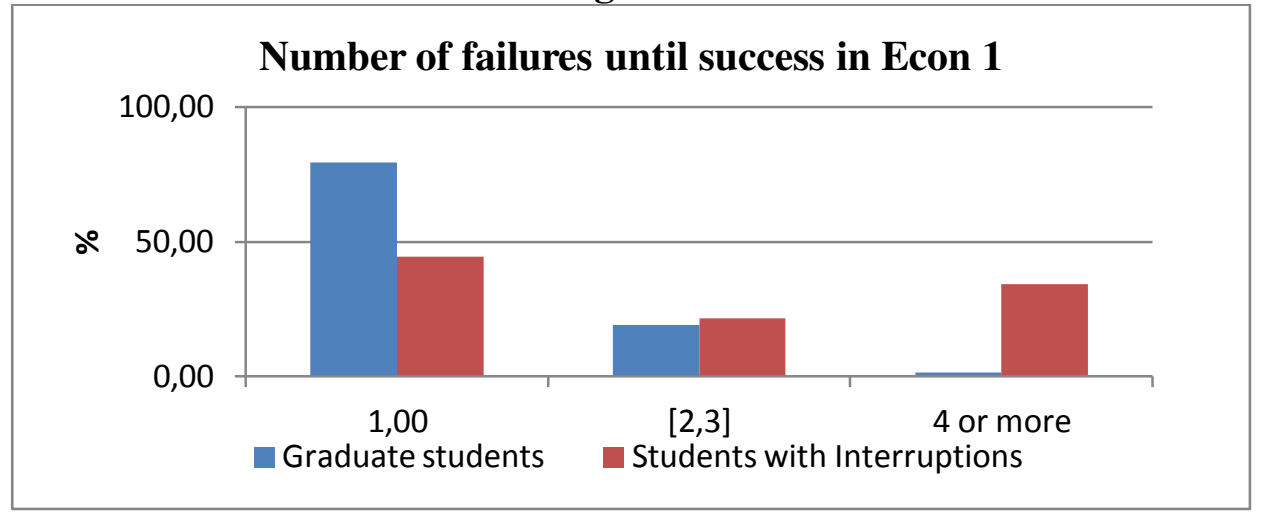

Figure 8

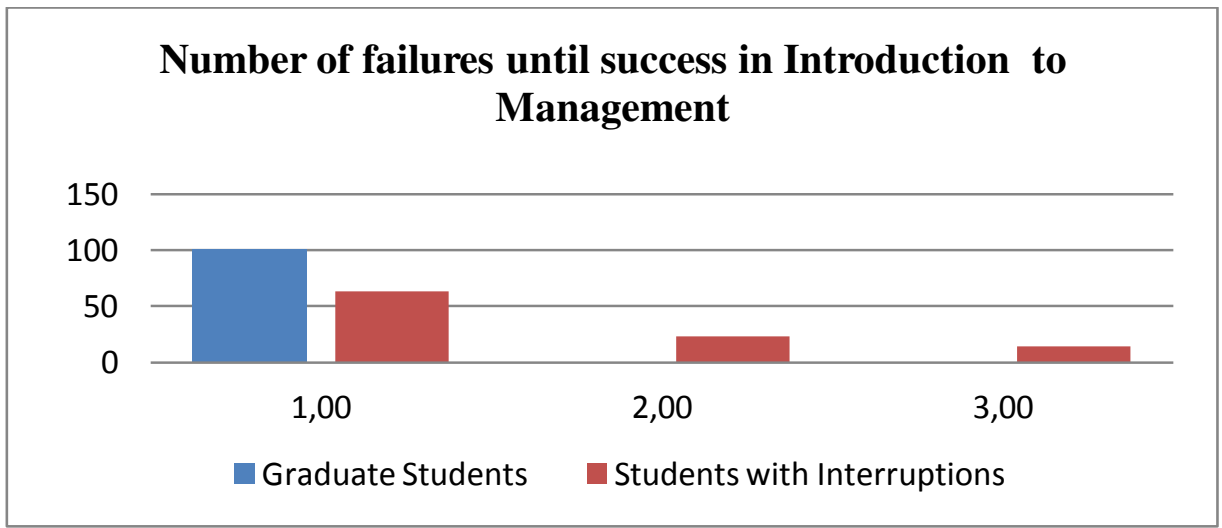

In the random sample of graduate students there are as many males as females, they are younger than those who interrupted (70.8\% are aged between 17 and 18 years old on entry to HE), and all unmarried. Most of them have not participated in the labour market (94.3\%). Like their colleagues they were mainly attending the Management Graduation Programme $(55.8 \%)$ but their grade point average was better, close to 12 (out of 20) at the moment they completed graduation and they faced a low number of failures in the $1^{\text {st }}$ year core subjects of HE as shown by Figures 6, 7, 8. 
Comparing parents' level of education between the two groups in Figures 9 and 10 we can conclude that parents' level of education is lower for the graduate students than for those who suffered interruptions in their HE trajectory.

Figure 9

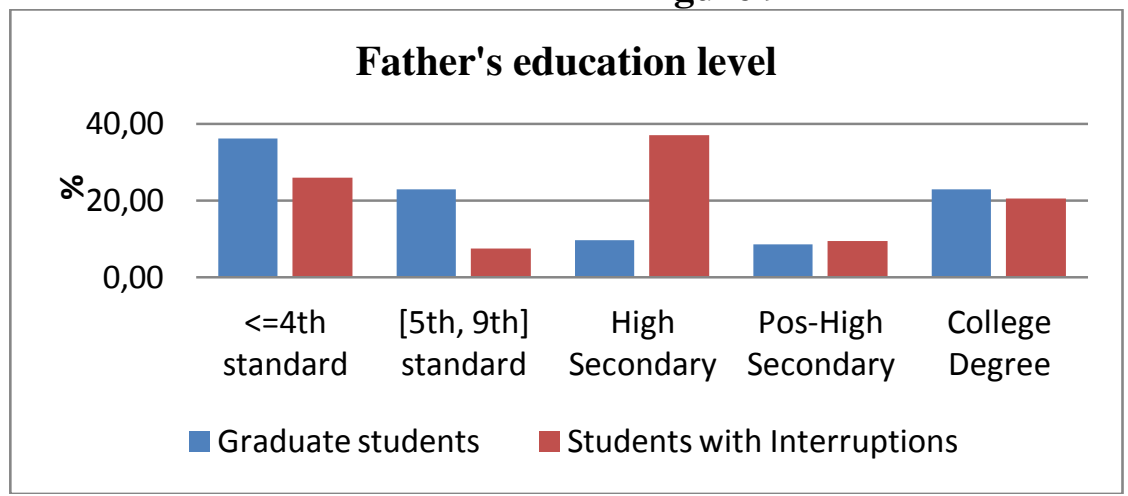

Figure 10

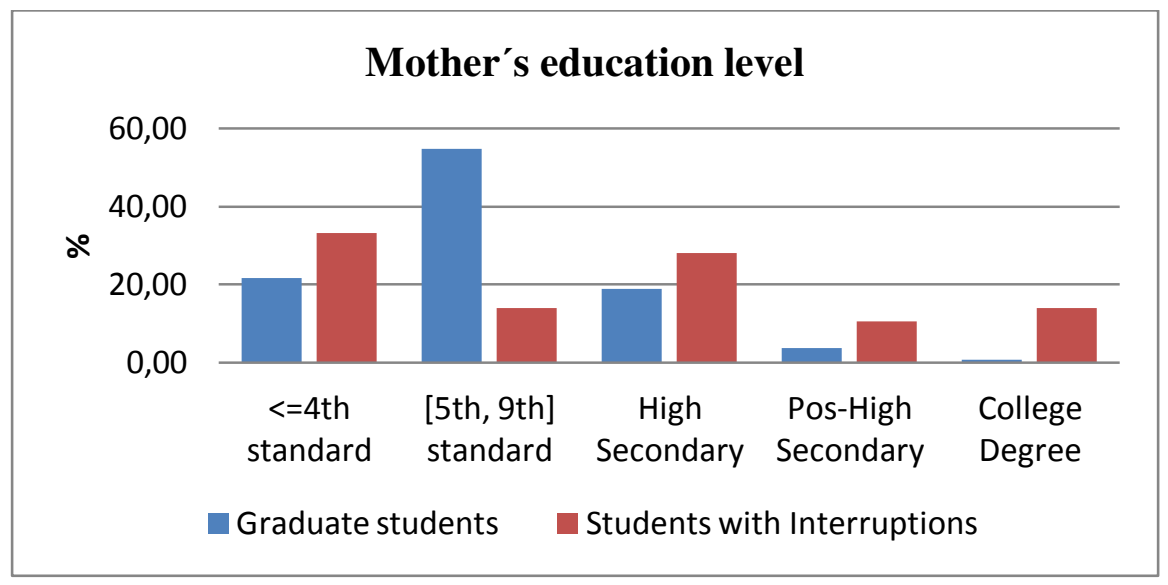

In a previous study, carried out on ISEG' students in $2008^{7}$, we found that there was a significant number of parents with low educational levels but high occupational levels ${ }^{8}$. Occupational levels might have more influence on parents' well being and in consequence on the studying opportunities they offer their children. This is a possible explanation for the above result. However we have no data on

\footnotetext{
7 “Alunos do $1^{\circ}$ ciclo do ISEG: Quem são? Alunos, famílias e percursos escolares em 2008/09” - ISEG Pedagogic Observatory.

${ }^{8}$ Figures in Appendix 1 show some evidence that supports this hypothesis.
} 
parents' occupational levels in the present database so we cannot confirm this hypothesis.

In both groups a great majority of fathers and mothers are employed [Figure 11]. Nevertheless, the percentage of parents' unemployed or out of the labour market is slightly greater for students with interruptions than for their colleagues' counterpart:

Figure 11

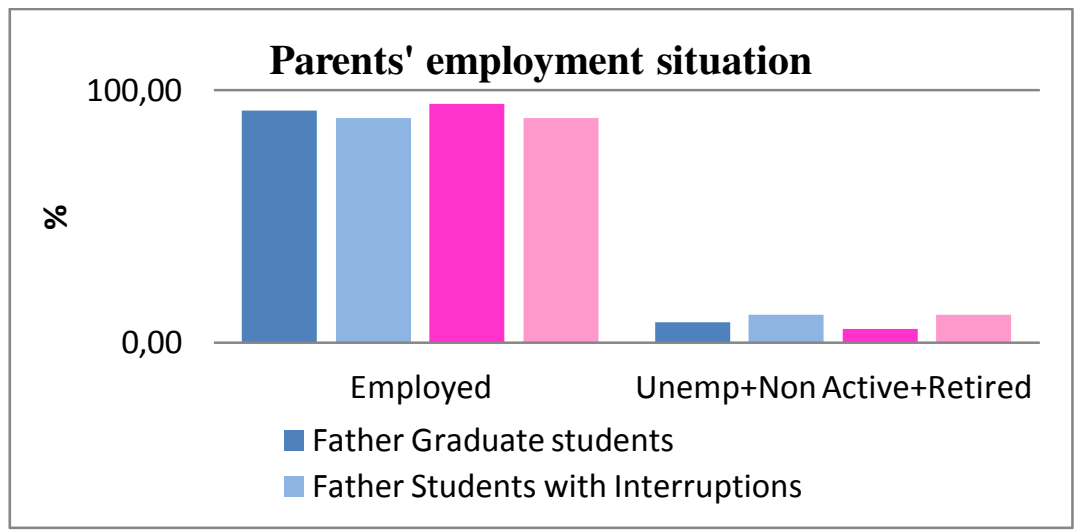

From Table 2 we can see that the distribution of gender, graduation program, and parents' situation towards employment are independent of the group to which the observation belongs. This means that the two groups cannot be distinguished by these variables. By contrast, the two groups are different with regard to civil status and participation in labour market [5\% significance level].

Table 2 - Chi-Square Test of Association

\begin{tabular}{|l|l|l|l|}
\hline Variables & $\begin{array}{l}\text { Chi-Square } \\
\text { Statistic }\end{array}$ & $\begin{array}{l}\text { Degrees } \\
\text { Freedom }\end{array}$ & p-Value \\
\hline Gender & 1.355 & 1 & 0.244 \\
\hline Civil Status & 5 & 1 & 0.024 \\
\hline Participation in the labour market & 67.814 & 1 & 0.000 \\
\hline Degree programme & 0.067 & 1 & 0.796 \\
\hline $\begin{array}{l}\text { Father's situation towards } \\
\text { employment }\end{array}$ & 0.341 & 1 & 0.559 \\
\hline $\begin{array}{l}\text { Mother's situation towards } \\
\text { employment }\end{array}$ & 1.972 & 1 & 0.16 \\
\hline
\end{tabular}


The results for the Mann-Whitney Test [Table 3] confirm that civil status and participation in labour market are different for students with interruption episodes and their more successful counterparts. Some of the former are married whereas none of the latter is and the proportion of those who participate in labour market is much higher among the former (62.9 as opposed to $5.7 \%)$.

Table 3 - Mann-Whitney Test

\begin{tabular}{|l|l|l|}
\hline Variables & $\begin{array}{l}\text { Mann- } \\
\text { Whitney } \\
\text { Test }\end{array}$ & p-Value \\
\hline Civil status & 4187 & 0.048 \\
\hline Participation in the labour market & 1588 & 0.000 \\
\hline Degree programme & 3978 & 0.796 \\
\hline $\begin{array}{l}\text { Father's situation towards } \\
\text { employment }\end{array}$ & 2453 & 0.485 \\
\hline $\begin{array}{l}\text { Mother's situation towards } \\
\text { employment }\end{array}$ & 3678.5 & 0.002 \\
\hline
\end{tabular}

However with this more appropriate test we can also see that mother's situation towards employment distribution is also significantly different between the two groups; the students with interruption episodes have a greater percentage of nonemployed (unemployed, non-active or retired) mothers (11 against 5.9\%).

The t-Test to Compare Means for two Independent Samples results in Table 4 gives us some interesting insights into the differences between the two groups:

Table $4^{9}:$ t-Test to Compare Means

\begin{tabular}{|l|l|l|l|l|}
\hline Variables & $\begin{array}{l}\text { Mean } \\
\text { Difference }\end{array}$ & $\begin{array}{l}\mathrm{t}- \\
\text { Statistic }\end{array}$ & $\begin{array}{l}\text { Degrees } \\
\text { Freedom }\end{array}$ & $\mathrm{p}$-Value \\
\hline Age at entry to HE & -0.666 & -3.705 & 186 & 0.000 \\
\hline Father's level of education & -0.458 & -1.172 & 157 & 0.243 \\
\hline Mother's level of education & -0.975 & -3.083 & 78 & 0.003 \\
\hline
\end{tabular}

\footnotetext{
9 The results in this table were calculated according to the results of Levene's Test for Equality of Variances reported in appendix 2.
} 


\begin{tabular}{|l|l|l|l|l|} 
HE entry exam mark & 0.961 & 2.041 & 85 & 0.044 \\
\hline $\begin{array}{l}\text { Number of failures until } \\
\text { success } \\
\text { in Math 1 }\end{array}$ & -2.676 & -7.12 & 84 & 0.000 \\
\hline $\begin{array}{l}\text { Number of failures until } \\
\text { success } \\
\text { in Econ 1 }\end{array}$ & -0.743 & -4.739 & 116 & 0.000 \\
\hline $\begin{array}{l}\text { Number of failures until } \\
\text { success } \\
\text { in Introduction to } \\
\text { Management }\end{array}$ & -0.537 & -4.454 & 81 & 0.000 \\
\hline
\end{tabular}

From these results we can say that:

father's level of education is not significantly different between the two groups but there are significant differences in age at entry to HE, mother's level of education and the performance variables before and after entering HE;

students who experienced gaps in their HE trajectory were older than those who did not at the moment they enter HE, which may be due to the existence of retentions or gaps in their previous education trajectory;

mother's level of education is lower among the more successful students;

graduate students had better marks in their HE entry exam than those with interruptions;

number of failures until success is higher for students who experience interruptions than for those who graduate in due time. Moreover this number is much higher for Math 1 than for Economics 1. Introduction to Management presents even lower values than the above two. This confirms previous results 10 that show that the number of failures increases with the degree of complexity of the subjects.

\footnotetext{
${ }^{10}$ Leão Fernandes e Chagas Lopes (2008).
} 


\section{Qualitative Data}

Given that a large number of students systematically miss either classes or final examinations, the Pedagogic Observatory of ISEG launched a Survey on Quitting and Interruption in order to assess the magnitude of those processes. This survey was carried out in January 2009 with a sample of students who had quit or had interrupted their studies in any one of the three ISEG degree programmes (Management, Economics, Applied Math) for which the first enrolment date lies between any of the academic years 1999/2000 and 2002/2003. Interruption spells up to 5 years were retained as interruption and separation spells longer than 5 years were considered as quits.

The very small number of answers to the questionnaire (14 out of 208) precludes any quantitative analysis. Nevertheless a brief review of the results obtained is useful as they complement the quantitative analysis.

Most students who interrupted are male, were attending the Management Programme at ISEG and recurrently repeat enrolment after the interruption. Most of them had chosen the Economic and Social track at Upper Secondary and when they interrupt they seem to be better vocationally oriented than most of their colleagues, particularly those who quit, despite their lower grade at the application to ISEG. The major reason behind this pattern seems to be these students' situation towards the labour market: most of them were already performing a paid work when they first enrolled in ISEG, a percentage that becomes meaningfully higher at the moment they break off.

The main reason presented for interruption is the impossibility of reconciling study and work schedules, an outcome which strongly differs from quitting students who emphasize disliking the degree programme and/or ISEG. More than half among the interruption students expressed their intention of rejoining ISEG and completing the programme, or coming back for a Master. 


\section{Conclusions and policy implications}

This was our first approach to the study of interruption and failure in HE, which we intend to develop further once we can rely on a more robust database that includes more observations and more information, namely, on parents' occupational levels and students' school trajectory prior to their entry to HE.

From this analysis we found evidence for several determinants of students' interruption of their HE trajectory mentioned by previous research on this field ${ }^{11}$, such as: individual and family characteristics; factors associated with greater responsibilities in adulthood (civil status, participation in labour market), and important features related with the HE institution's organisation procedures ( time scheduling, class groups).

The results from quantitative and qualitative analyses show us that when compared to their graduate colleagues:

- Students with interruption occurrences in HE trajectory are older when they enter HE, because their school trajectory prior to HE had already been marked by retentions and interruptions;

- They are more often married and have larger financial responsibilities urging them to enter the labour market;

- Most of them were already performing paid work when they first enrolled in ISEG, a number that increases by the moment they interrupt;

- Mothers' education level and situation towards employment determines their HE trajectory;

- Mothers' education level is negatively associated with students'academic performance which goes against our expectations;

- They join HE with lower grades in the entry exam which also points to the fact

- They were already less successful in their prior school trajectory than their colleagues;

- They register more failures in the three core subjects of $1^{\text {st }}$ year of HE (Math, Economics and Introduction to Management).

\footnotetext{
${ }^{11}$ Namely those studies mentioned in section 2 .
} 
Thus we can conclude that prior school trajectory with retention and/or interruption episodes made these students reach $\mathrm{HE}$ at an older age than their graduate colleagues and consequently more prone to increased responsibilities associated with adulthood like being married. These constraints prompt the need to perform paid work, this sometimes occurring even before entering HE.

The lack of flexibility of most HE institution's organisation procedures (absence of part-time programmes, class dimensions , evaluation methods...) as well as perceived quality of teaching makes it difficult for students to reconcile study and working schedules leaving these students no other option than to interrupt their studies.

However, these students, who frequently followed the Economic and Social track at Upper Secondary, seem to be well vocationally oriented since they keep trying to finish their degree and state that graduation is a life goal. Many of them have HE trajectories characterised by four or more successive occurrences of interruptions - enrolments - interruptions- $\cdots$. In further developments, we intend to develop a more systematic analysis on this subject following the methodology proposed by Makinen et al (2004).

In this study we had no opportunity to analyse either the impact of experience and skills acquired throughout occupational performance on academic knowledge, as in Jacob and Weiss (2008), or on the success/failure of students in spite of the longer time spells needed to complete the degree due to interruptions. According to the spirit of the Bologna Process, a better link between matters taught in subjects at the university and on the job experience - preferably in the form of internship - would be crucial for both professional and academic performance enhancement. The Portuguese HE reality is currently still very far from this scenario. However the fact that students with discontinued $\mathrm{HE}$ trajectories display several sequences of enrolments - interruptions within the same degree programme and institution points to the existence of reasonable links between academic subject contents and the skills developed on the job in spite of the difficulties in conciliating study and work schedules. 
To foster lifelong learning has been seen as a major goal of governments in recent years. Lately, the idea that $\mathrm{HE}$ is a fundamental tool for the extension of lifelong learning has gained more and more support, not only because the young population coverage has been growing but also due to the need to increasingly capture new strata of the population. The spirit of the Bologna Process and its contribution to lifelong learning development will only be fulfilled if HE institutions' organisation procedures and degree contents can change so that they are able to offer better conditions for the conciliation of study and work (Pausits \& Pellert 2009; EC 2010; ISEG Pedagogic Observatory 2010).

Portuguese HE has not yet been able to fulfil these conditions although specific laws to ease the admission of students aged over 23 have been implemented since 2007/08. This implementation has not yet succeeded in changing these students' study conditions, so there is still effective inequality for these adults' opportunities for better academic performance.

To attract adult students is very important for the financing of public $\mathrm{HE}$ institutions. Yet, if a growing percentage of students (not reachable without the adult students due to the declining demographic trend) contribute positively to the public budget endowment, the high failure rates play a negative effect. HE institutions benefit from the differentiation between students with retention episodes (potentially non-motivated ones) and those who successively interrupt their school trajectory because they cannot conciliate study and work. These work and study oriented students, will most probably contribute to reducing deadweight losses and so improve HE institutions' budget. So institutions should provide them with more adequate framing conditions.

Portuguese students have comparatively heavy average cost with HE than their colleagues in other EU countries and the public support in the form of grants or subsidies is low (Table 1). Therefore Portuguese HE students have to perform a paid work to finance their studies more often than their EU colleagues. This certainly has a negative impact on academic performance. 
To help students whose academic performance is conditioned by the need to perform a paid job while studying, new proposals towards the reinforcement of government educational social policy are welcome, especially those which lead to a public loans policy potentially warranted by public or semi-public risk capital [Cerdeira (2009)]. For the students already in the labour market partnership or contract programs between HE institutions and the employer organisations seem particularly advisable since they are compatible with public resources constraints and may raise genuine partnership processes with mutual co-liability among all stakeholders: students, HE institutions, employers and government.

These issues should be considered by HE institutions' management, particularly now when HE institutions are opening to lifelong learning.

Now that the Bologna Chart took away the responsibility from Government of financing the $2^{\text {nd }}$ cycle, making the students pay for it, the need to reconcile studying with paid work is even greater.

Financial and budgetary policies in HE also should take interruptions into consideration. As a matter of fact, financial policy affecting public universities relies on different success/failure and quality indicators. By distinguishing retention from interruption processes we are able to clarify the internal versus exogenous nature of the obstacles affecting success.

From the students' point of view interruptions are equivalent to longer time spells to complete the degree programme. Moreover an increased need to earn money enough to finance the studies goes along increased difficulties of achieving a successful academic performance. This is even truer because the percentage of HE institutions with part-time academic programmes are not significant in our country.

The interruption spells and the amount of time required to graduate are not neutral for the individuals' or the HE institution. The former should internalize this kind of eventual losses when addressing the cost-benefit analyses associated with prolonging studies as they exert multiple direct and opportunity costs: weaker ties to family and occupation trajectories, raising difficulties in forecasting labour market 
opportunities following graduation, a supplementary income effort... The government should also revise social policies addressed to HE students not only in terms of fellowship and loan policies (Cerdeira 2009) but also reassessing the articulation between Secondary education and HE degrees as well as providing more efficient information and consultancy advice regarding labour market insertion for graduates. In any case, not only private but also the social rate of return to education will be affected by interruption.

Administrative and pedagogic HE institutions' organisation and models have to be reassessed and redesigned in order to allow for studying and occupational performance to be reconciled, namely by considering part-time academic programmes. Also, gross failure rates have to be broken down in order to isolate retention rates due to interruption (and quitting) for budgetary purposes as they affect funding eligibility differently. 


\section{Bibliography}

- Becker, G. (1964), Human Capital: A Theoretical and Empirical Analysis, with Special Reference to Education, Chicago: University of Chicago Press (1964; 1993 3rd. Ed).

- $\quad$ Bidart, C. and Lavenu, D. (2005), "Evolutions of personal networks and life events", Social Networks, 27(2005), 359-376 (Acc: http://halshs.archivesouvertes.fr/docs/00/05/25/50/pdf, the $12^{\text {th }}$ July 2009).

- Cerdeira, L. (2009), “O Financiamento do Ensino Superior Português. A partilha de custos", doctoral thesis, Lisbon, University of Lisbon.

- Chagas Lopes, M. (2007), "Formação Profissional e Crise do Emprego", Cadernos Sociedade e Trabalho (IV) - Formação Profissional, Lisbon, Ministério da Segurança Social e do Trabalho.

- Chagas Lopes, M. e Leão Fernandes, (2008) “Success/Failure in Higher Education: how long does it take to complete some core 1st. year subjects?" (coauthor).ECER Conference "From teaching to learning", September, Gotemburg, Sweden.

- $\quad$ EC (2007), Key Data on Higher Education in Europe, Luxembourg, Eurydice \& Eurostat, Acc.

http://eacea.ec.europa.eu/ressources/eurydice/pdf/0_integral/088EN.pdf , the 23rd February 2010.

- $\quad$ EC (2010), "Focus on Higher Education in Europe 2010: The Impact of the Bologna Process", EURYDICE, (Acc. http://eacea.ec.europa.eu/about/eurydice/index_en.htm, December 2010)

- $\quad$ EUROSTAT Database (Acc http://epp.eurostat.ec.europa.eu/portal/page/portal/statistics/search_database, 23rd February 2010)

- ISEG Pedagogic Observatory (2010), Report on the impacts of the Bologna Reform on Academic Success in ISEG”, Conference Paper, ISEG, October 2010.

- Jacob, M. and Weiss, F. (2008), "From higher education to work - patterns of labour market entry in Germany and the US", Arbeitspapiere - Zentrum für Europäische Sozialforschung, $n^{\circ} 110$ (Acc: http://www.mzes.uni-manheim.de in $5^{\text {th }}$ July 2009). 
- Leão Fernandes e Chagas Lopes, M., (2008) "ISEG undergraduate students: determinants of academic performance" (co-author). ECER Conference "From teaching to learning", September, Gotemburg, Sweden.

- Lüede, R. (2009), Less rather than more internationalization? Unintended effects of the Bologna Process, Revista de la Educación Superior, Vol XXXVIII (3), No 151Makinen, J., Olkimora, E. and Lonke, K. (2004), “Students at risk: students' general study orientations and abandoning/prolonging the course of studies", Higher Education (48:2).

- $\quad$ Mincer, J. (1958), "Investment in Human Capital and Personal Income Distribution", The Journal of Political Economy, vol. LXVI (4).

- Musselin, C. (2009), "The side-effects of the Bologna Process on National Institutional Settings: the case of France”, Higher Education Dynamics, vol 26, Part III.

- OECD (2002), Education at a Glance - Glossary of Statistical Terms (Acc: http://stats.oecd.org/glossary/detail.asp?ID=5441, 30 ${ }^{\text {th }}$ May 2011).

- $\quad$ OECD (2009), Education at a Glance (Acc: http://www.oecd.org/document/24/0,3343,en_2649_39263238_43586328_1_1_ 1_1,00.html, $25^{\text {th }}$ February 2010).

- $\quad$ Parri, J. and Aas, K. (2006), "National examination scores as predictors of university students' performance in Estonia", University of Tarty, Trames, 10(60/55), 3, 255-267 (Acc. http://www.kirj.ee/public/trames/trames-2006-34.pdf, the $14^{\text {th }}$. September 2009).

- $\quad$ Parvan, S.-V. (2007), Statistics in Focus, no 116, EUROSTAT, Acc http://epp.eurostat.ec.europa.eu/cache/ITY OFFPUB/KS-SF-07-116/EN/KS-SF07-116-EN.PDF, April, 28 ${ }^{\text {th }}, 2011$ ).

- $\quad$ Pausits, A. \& Peller, A. (2009), "The Winds of Change: Higher Education Management Programmes in Europe", Higher Education in Europe, 1469-8358, Volume 34, Issue 1, 2009, Pages 39 - 49,(PORDATA, http://www.pordata.pt/azap_runtime/?n=4).

- Scott, M.A. and Bernhardt, A. (2000), "Pathways to educational attainment: their effects on early career development", Institute on Education and the Economy, IEE BRIEF no 28 (Acc. http://edr.sagepub.com/cgi/content/abstract/30/1/5, the 12th. June 2009). 
- Teleshova, I.G. et al (no data), Factors determining accessibility of complete higher education at an elite higher education institution: example of the Lomonosov Moscow State University, Moscow, Moscow State University. (Acc. http://www.socpol.ru/eng/research_projects/proj5_digest.shtml, the $10^{\text {th }}$ July 2009).

- Yorke, M. \& Longden, B. (2008), The first-year experience of higher education in the UK - Final Report, London: The Higher Education Academy.

- Willis, R.J. (1987), "Wage determinants: a survey and reinterpretation of human capital earning functions", Handbook of Labour Economics, Orley Ashenfelter and Richard Layard (publ.), London and New York, North Holland, pp. 525602. 


\section{Appendix 1}
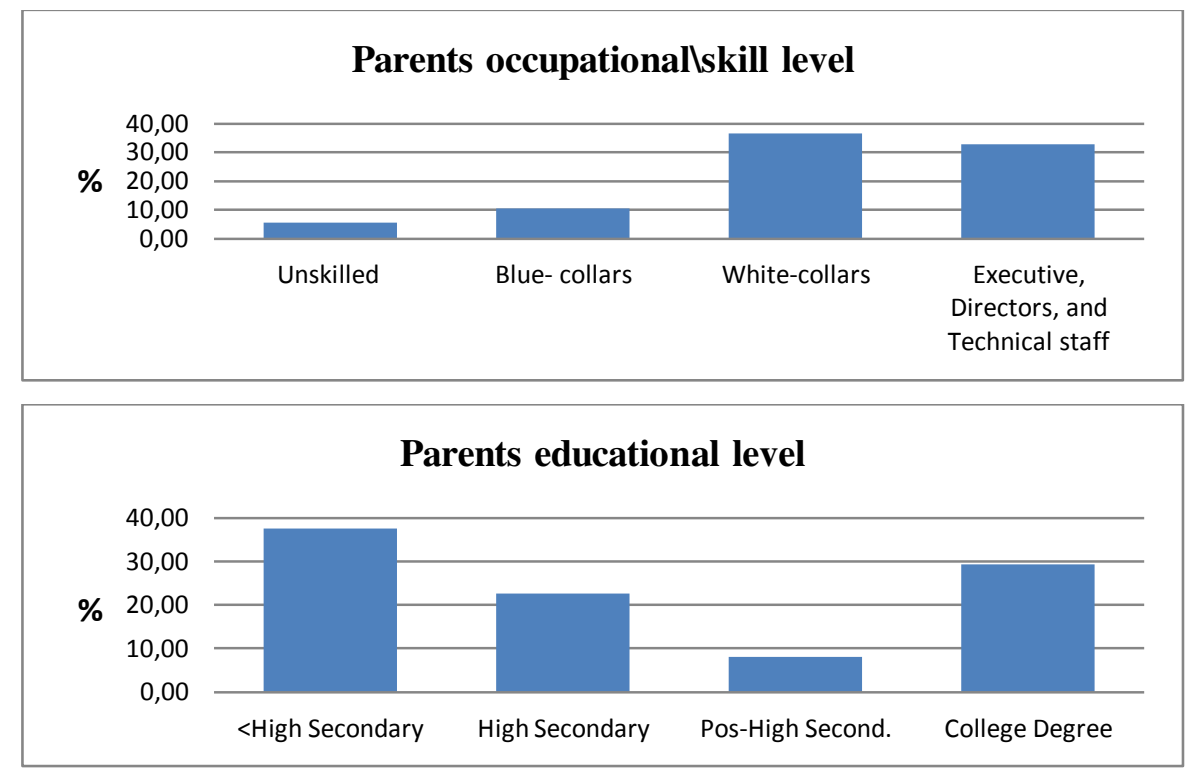

Appendix 2

\begin{tabular}{|l|l|l|}
\hline Variables & F - Statistic & p-Value \\
\hline Age at entry to HE & 3.824 & 0.052 \\
\hline Father's level of education & 2.806 & 0.096 \\
\hline Mother's level of education & 26.952 & 0.000 \\
\hline HE entry exam mark & 0.919 & 0.34 \\
\hline Number of failures until success in Math 1 & 136.212 & 0.000 \\
\hline Number of failures until success in Econ 1 & 35.643 & 0.000 \\
\hline $\begin{array}{l}\text { Number of failures until success in } \\
\text { Introduction to Management }\end{array}$ & 104.96 & 0.000 \\
\hline
\end{tabular}


